 \\ Journal of \\ Human, Earth, and Future
}

ISSN: 2785-2997

Vol. 2, No. 3, September, 2021

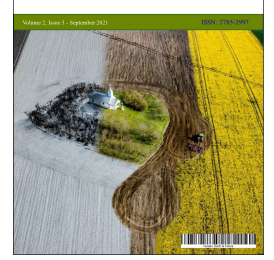

\section{The Impact of the Fourth Industrial Revolution on Ethical Leadership}

\author{
Thanh Nguyen Hai ${ }^{1 *} \odot$, Quang Nguyen Van ${ }^{1}$ \\ ${ }^{1}$ Institute of Leadership and Public Policy, Ho Chi Minh National Academy of Politics, Hanoi, Vietnam
}

Received 11 June 2021; Revised 14 August 2021; Accepted 22 August 2021; Published 01 September 2021

\begin{abstract}
Objectives: ethical leadership is a widely discussed topic, but so far there are still debates about it, even arguing that ethical leadership is just statements of right and wrong or that it is a "leadership style". Now, the impact of the fourth industrial revolution will make ethical leadership even more essential to improving leadership performance. Therefore, the aim of the study is to show the advantages and challenges of the fourth industrial revolution and their impacts on ethical leadership so that the effects are useful to leadership performance. Focus on developing ethical leadership. Methods / Analysis: This study conducts analysis and evaluation from data sources on Science Direct, Web of Science, and Scopus, thereby showing the basic characteristics of leadership; ethics; ethical leadership; the fourth industrial revolution; advantages and challenges; and discussions on the impact of the fourth industrial revolution on ethical leadership. Findings: The findings of the study indicate that the ethical leadership qualities are quite stable, such as perseverance, service spirit, tolerance, power sharing, fairness, etc. The impact of the fourth technological revolution will make ethical leaders more effective in their roles, making it easier for leaders to overcome challenges, contributing to improving leadership performance. Novelty / Improvement: Research shows that ethical leaders will be dedicated leaders, service-minded leaders, impacted by the fourth technological revolution, making leadership even more powerful. Virtue is becoming more and more important. Therefore, in order to successfully implement the fourth industrial revolution, it is necessary to pay attention to developing ethical leadership.
\end{abstract}

Keywords: Leadership; Ethical Leadership; The Fourth Industrial Revolution; Ethical Leadership Development.

\section{Introduction}

The first ideas about morality appeared quite early in antiquity. In the East, moral ideas associated with the doctrine of virtue were initiated by Confucius (551-479 BC) and further supplemented by Mencius (372-289 BC) and Xunzi (298-238 BC), and development, emphasizing values such as filial piety, loyalty, based on the duty of the individual, seen as an obligation to ensure the smooth functioning of society rather than protecting individual rights. In the West, prominent philosophers such as Plato (427-347 BC), Aristotle (384-322 BC) argued that the basis of morality is to maintain social order or, for religious reasons, people fulfil a moral obligation to others in society [1]. Over time, the concept of morality seems to have little change, even when the concept of morality is approached from different angles, the values are as common as with universal values such as: respect, service, integrity, fairness, honesty, responsibility, and honesty continue to be widely recognized.

* Corresponding author: thanhhaitlh@gmail.com

doi) http://dx.doi.org/10. 28991/HEF-2021-02-03-05

$>$ This is an open access article under the CC-BY license (https://creativecommons.org/licenses/by/4.0/).

(C) Authors retain all copyrights. 
Not only recognizing the universal values of ethics, the concept of ethics was extended to leadership science and was strongly developed before new theories of leadership to promote and guide the development of leadership. Organizations and societies overcome new leadership challenges and contexts that management theories cannot address [2]. Studies give many diverse conceptions of ethical leadership in many different fields, but the common point between the studies is that ethical values are an important content in leadership and leadership that is not ethics becomes a counter-value. Therefore, ethics and leadership are two inseparable components in ethical leadership [3]. Among the studies that acknowledge the universal values of ethical leadership, some point towards making right and wrong arguments or seeing ethical leadership as just a style of ethical leadership [4]. In fact, it will be difficult to assert that ethical leadership is only right or wrong if it is not tied to specific cultures, leadership contexts and situations, and historical circumstances.

Studies have proven and shown that ethical leadership in the long run has little change, but with the advent of technological revolutions, and recent major technological revolutions have made some values, standards, and ethical qualities have changed, the more advanced the technology, the more impact, and may even shake some long-standing ethical leadership foundations [5]. Before the assertion of the two authors Bernard and Ronald, so far, there has been no research to prove or disprove the above statement, this silence seems to have shown agreement with the assertions that Bernard and Ronald gave out.

Facing the impact of advanced technology, especially the fourth technology revolution, has increased a large number of challenges for many organizations, but not all organizations can easily overcome. Having good leadership skills is not enough if the leader lacks patience, lacks ethical leadership [6]. Therefore, not every leader can easily overcome all leadership challenges when the leader himself does not prepare himself and organize new skills to be able to adapt to the leadership context [7]. The emergence of the leader is always associated with the emergence of leadership challenges, and ethical leadership will make the leader more consistent in leadership strategies.

However, the impact of the fourth technological revolution has a profound impact on the entire social life, it can change the way we live and work. Therefore, the goal of this study is to analyze, evaluate and discover and discover the ethical leadership qualities required for a leader to overcome the impact of the revolution. The fourth technology network, from which there are suggestions for developing ethical leadership to adapt to the advantages that this revolution comes to us, the leader will be the pioneer to receive and lead the organization. Organizations and society achieve development. Moreover, leaders need to have bravery and practice and develop ethical leadership to overcome challenges and unwanted temptations caused by the impacts of the fourth technological revolution. Incompetence in ethical leadership can lead to unethical leadership outcomes [8]. Therefore, it is necessary to accept the positive effects of the fourth industrial revolution based on ethical leadership standards and principles.

\section{Definition of Ethics and Ethical Leadership}

\subsection{Ethic}

Ethics is a concept that has become familiar to mankind over many years of history, most of which recognize it as a system of rules and standards of the community and society that people acknowledge and voluntarily follow. Dao is the way, virtue is the good quality that a person has to practice to acquire virtue. Le (2011) pointed out that morality is a law that happens around us and does not depend on anyone's personal will [9]. Ethics is not an innate factor, but each subject has to learn and practice to form ethical standards, that is, people voluntarily adjust their behavior in accordance with the values. Standards of the community and society. Different fields, different cultures, people can have different and even opposing standards and opinions. For example, in medical tests on animals, some are supportive, others are opposed. Therefore, morality is a form of social consciousness, it was born with the appearance of human society, people set themselves and voluntarily adjust their behavior according to the standards that were previously set [10].

As a form of social consciousness, morality is not constant, it is both social in nature and class in nature. In class societies, the ruling class will dominate social morality. When society moves to a high level of social democracy, the moral category becomes a universal value, so it is highly social and can be adjusted to many relationships in society at different levels certain degree to which an individual voluntarily practices ethical behavior [11]. The concept of morality will change with the change of social life, but ethical categories seem to have little change over time such as good and evil, good and bad, dos and don'ts, etc. and universal values such as duty, conscience, gratitude, reason, etc. seem to be widely accepted [12].

According to Dancy (2005) [13] morality has no principles, it is just the behavior that should or should not be done by individuals in society. He has no concrete evidence to prove morality has no principles. However, the majority of studies confirm that morality is principled, that people set and voluntarily follow but according to certain standards and are adapted to each certain cultural context, with the requirements of the field of activity [14, 15]. Wang Haiming [16] also asserted, morality has a certain principle, a standard in a culture, a field of activity that everyone performs 
with the same behavior, when the behavior follows the standard. Standards will be considered as deviating from standards, as a violation of ethical principles. On the basis of monitoring the change of conceptions and ethical standards over time, it can be seen that morality is a form of social consciousness, universally recognized normative principles, in order to regulate relationships. Relationship between people in society.

\subsection{Leadership}

In the 1980s and 1990s, the science of leadership was so extensively studied that an official bibliography of 8,000 leadership studies was established. Murphy and Cuban (1990) compiled more than 350 different definitions of leadership. These definitions share some common terms such as "process", "influence", "situation", "purpose", "organization", "value", “creation", “quality", “individual”, "vision", and "change". Murphy and Cuban (1990) defines leadership as influencing the actions of others to achieve desired goals, and management as effectively and efficiently maintaining existing organizational structures $[17,18]$. The basic argument that needs to be emphasized and clarified is the need for critical research, inheritance and development of leadership science.

According to Stogdill (1974), there are many different definitions and try to define the meaning of this concept [19]. Trying to find a widely accepted definition of leadership has inspired researchers, which is difficult because the definitions seem to approach from the point of view of cultures and cultures in different contexts [20]. After much debate, studies have come to some consensus that leadership is not a step, but a process, an activity and an expression of competence [10, 21-23]. At the same time, studies show that, in order to carry out leadership activities, one must learn and develop over time and practical experience, even leaders are considered to have "natural leadership capacity". "students", must also go through a process of training, accumulating experience, and if they want to lead effectively, leaders must not cultivate leadership capacity.

Despite these admissions, perspectives on leadership are constantly being added. According to Bass (2009), leadership is an interaction between two or more members of a group that often involves a structuring or restructuring of the situation and the perceptions and expectations of members. Leadership occurs when one group member modifies the motivation or competencies of others in the group. Any member of the group can exhibit some amount of leadership [24]. Jacob and Jaques (1990) [20], define leadership as a process of giving purpose or meaningful direction to collective effort and causing willing effort to be extended to achieve purpose. Rebore (2003) consider leadership as "a way of life of dedication to the academic community and profession [25]. In essence, this concept is limited to dedication and is associated with the academic and professional community. Silva (2016) [26] argues that leadership is the process of interactive influence that occurs when, in a given context, some people accept someone as their leader to achieve common goals. According to this concept, leadership is the act of making others voluntarily, not using coercion. Maxwell (2016) sees leadership as the process of influencing, nothing more, nothing less [27]. This concept is too broad in connotation because not all influence processes are considered leadership.

The concept of leadership continues to be expanded in connotation, depending on the research field, the authors may give different conceptions. Therefore, it is difficult to have a universally accepted definition of leadership, but values such as democracy, justice, integrity, influence process, commitment, voluntariness, leadership, example, service, etc. are the values that the religious activity or the leadership process in any organization should aim for.

\subsection{Ethical Leadership}

It seems that the sustainable development and performance of organizations are closely related to ethical leadership, so from the 1980s to the present day, the concept of ethical leadership is found in experiments. These studies [28-33], quite agree that ethical leadership is an integral part of the leader's qualities, reflected in the leader's behavior with responsibility, the voluntary dedication of their own values to the organization, the leader is considered a central model in behavior for employees to follow. Gini (1997) argues that leadership and ethics are inseparable, an ethical foundation is necessary because it acts as a guide for ethical and consistent choices for leaders to rely on. In decision making and action [34].

Kanungo and Mendonca (1996) [35] argue that when a leader is based on ethical leadership, he will have a spirit of service and always know how to influence to lead the organization to achieve its mission, vision, and achievement. "stated leadership goals". When a leader sets goals, the organization's mission as the ultimate goal means that the leader will strive to strive for, make and practice leadership decisions based on the consensus of the organization, never now consider leadership as a means to achieve individual goals, then ethical leadership becomes a common ethic and integrates into the organizational culture [36]. The common value mentioned is the spirit of service to realize the mission and goals of the organization. Not only that, the leader has altruism, tolerance, respect for employees as they deserve, the leader will become an example and behavioral standard for employees to follow without needing to follow administrative power, with leadership based on ethical standards, employees will be self-disciplined, moreover, the leader can inspire, motivate and motivate each person to promote their own values [2]. Leaders become an example, with altruism, kindness, tolerance, these values are common standards for leaders to influence and motivate employees to voluntarily carry out their tasks. 
In 2008, Hoogh and Hartog [37] added three components to ethical leadership and he considered this to be the structure of ethical leadership: equity values, power sharing, and leadership roles "virtue". In essence, these are just manifestations of ethical leadership or the values of ethical leadership. According to Yukl (2012), when ethical leadership is practiced regularly in the workplace, it will resonate and increase the performance of both leaders and employees. Here, ethical leadership has added new values that are fairness, sharing of power, power becomes common power becomes common power because each individual is a part of the organization, becomes a value. Everyone acknowledges and self-consciously [38].

According to Kitchener (1984) [39], ethical leadership has many similarities with democratic leadership, employees are promoted to their own values, are free to act and are free to pursue common goals, then Ethical leaders becomes the art of influencing, because moral leadership contains in it the general standards and principles of society because according to Rost [40] each person has his or her own, they need to be respected and respected. Each person must also respect the common standard, the leader himself must also follow the common moral standard [41]. Leadership ethical principles as behavioral patterns to motivate employees to work with a sense of responsibility and high sense of responsibility, protect justice, goodness, protect fairness and always fight against evil. These things make leadership more valuable and deepened when the leader is aware that it is one of the important manifestations that increase leadership effectiveness, requiring leaders to practice and practice ceaselessly and without compromise with immorality.

Besides the standards of ethical leadership, Mihelic et al. (2010) [42] agreeing the above points, they also believe that ethical leaders use power and authority according to position and law. Method to distinguish ethical leaders from militaristic, unethical leaders, but still emphasize values and behaviors that are consistent with the regulations of social institutions and institutions festival. The authors listed the characteristics that distinguish ethical leaders from unethical leaders Mihelič and Lipičnik listed eight behaviors of ethical and unethical leaders that can be demonstrated (Table 1).

Table 1. Ethical and unethical leadership

\begin{tabular}{cc}
\hline The Ethical Leader & The Unethical Leader \\
\hline Is humble & Is arrogant and self-serving \\
Is concerned for the greater good & Excessively promotes self-interest \\
Is honest and straightforward & Practices deception \\
Fulfils commitments & Breaches agreements \\
Strives for fairness & Deals unfairly \\
Takes responsibility & Shifts blame to others \\
Shows respect for each & Diminishes others' dignity \\
individual & Neglects follower development
\end{tabular}

Selznick et al. (2002) said that between ethical leadership and unethical leadership there is no criteria to distinguish, so he gave 8 criteria to distinguish (Table 2) [43]. So far, this distinction has been widely accepted because it shows aspects that were previously pointed out by many authors, and until now, the ethical leadership qualities do not seem to have supplemented the concepts, but mainly in the direction of adapting it to each specific leadership activity area.

Table 2. Criteria for evaluation of ethical leadership

\begin{tabular}{|c|c|c|}
\hline Criterion & Ethical Leadership & Unethical Leadership \\
\hline Use of leader power and influence & Serves followers and the organization & Satisfies personal needs and career objectives \\
\hline $\begin{array}{l}\text { Handling diverse interests of } \\
\text { multiple stakeholders }\end{array}$ & Attempts to balance and integrate them & $\begin{array}{l}\text { Favours coalition partners who offer the most } \\
\text { benefits }\end{array}$ \\
\hline $\begin{array}{l}\text { Development of a vision for the } \\
\text { organization }\end{array}$ & $\begin{array}{l}\text { Develops a vision based on follower input about their } \\
\text { needs, values and ideas }\end{array}$ & $\begin{array}{l}\text { Attempts to sell a personal vision as the only way for } \\
\text { the organization to succeed }\end{array}$ \\
\hline Integrity of leader behaviour & Acts consistent with espoused values & Does what is expedient to attain personal objectives \\
\hline $\begin{array}{l}\text { Risk taking in leader decisions } \\
\text { and actions }\end{array}$ & $\begin{array}{l}\text { Is willing to take personal risks and make necessary } \\
\text { decisions }\end{array}$ & $\begin{array}{l}\text { Avoids necessary decisions or actions that involve } \\
\text { personal risk to the leader }\end{array}$ \\
\hline $\begin{array}{l}\text { Communication of relevant } \\
\text { information operations }\end{array}$ & $\begin{array}{l}\text { Makes a complete and timely disclosure of } \\
\text { information about events, problems and actions }\end{array}$ & $\begin{array}{l}\text { Uses deception and distortion to bias follower } \\
\text { perceptions about problems and progress }\end{array}$ \\
\hline $\begin{array}{l}\text { Response to criticism and dissent } \\
\text { by followers }\end{array}$ & Encourages critical evaluation to find better solutions & Discourages and suppresses criticism or dissent \\
\hline $\begin{array}{l}\text { Development of follower skills } \\
\text { and self-confidence }\end{array}$ & $\begin{array}{l}\text { Uses coaching, mentoring and training to develop } \\
\text { followers }\end{array}$ & $\begin{array}{l}\text { Deemphasizes development to keep followers weak } \\
\text { and dependent on the leader }\end{array}$ \\
\hline
\end{tabular}


Ethical values incorporated into leadership activities become common codes of conduct, become standards in organizations, people voluntarily and voluntarily implement without the leader needing to use executive orders. Therefore, leadership performance also increases, even when the leader is not present, the leadership role and influence are still maintained, moreover, in the current leadership context there is a change. Quickly, a quality in ethical leadership is to dare to take responsibility, not to compete, and not to blame subordinates or employees [44] At the same time, ethical leadership will have a transformation, so ethical leadership itself becomes the art of leadership to influence employees. Ethical leadership is also reflected in the fact that leaders build and practice common ethical standards, values and principles in the organization in accordance with social institutions, in order to influence and inspire, and lead others to voluntarily follow the values chosen by the leader, in order to achieve the overall goals of the organization. More than 2000 years ago, Lao (1972) [45] said that a powerful leader is someone who even when not present, their power is still expressed through the free will of others. In the 21 st century, ethical leadership becomes even more essential when the values of democracy, justice, and responsibility are upheld [46].

\section{The Fourth Industrial Revolution: Opportunities and Challenges}

\subsection{The Fourth Industrial Revolution}

The birth and impact of the fourth industrial revolution brought drastic changes in power, wealth and new knowledge bases, new values for people's lives. However, only when we understand it and the effects it has on people's lives can we apply it, and thus ensure advances in knowledge and understanding. Technology will reach everyone and bring common prosperity to everyone. On the contrary, the fourth technological revolution will have no meaning if somewhere people do not learn, do not understand, this revolution has no meaning.

In 1760 with the memorable event that was the invention of the steam engine. From an agrarian society to a new production process, there were first applications of technology to increase productivity, typically the train transportation industry was put into use, the textile industry. Until 1900 marked the birth of the internal combustion engine, mankind knew how to use oil and electricity for mass production. Only 60 years later, in 1960 mankind entered the third industrial revolution which is characterized with the advent of electronics and information technology to automate production, human labor gradually. Liberated by machines to replace human labor. Humanity did not need to wait long, after the birth of the third industrial revolution in less than 40 years, the early 2000s marked the birth of the present fourth industrial revolution [47]. The development of the four industrial revolutions is summarized in Table 3.

Table 3. Main characteristics of industrial revolutions

\begin{tabular}{|c|c|c|c|c|c|}
\hline Period & Transition Period & Energy Resource & Main Technical Achievement & $\begin{array}{l}\text { Main Developed } \\
\text { Industries }\end{array}$ & $\begin{array}{l}\text { Transport } \\
\text { Means }\end{array}$ \\
\hline I: $1760-1900$ & $1860-1900$ & Coal & Steam Engine & Textile, Steel & Train \\
\hline II: $1900-1960$ & $1940-1960$ & Oil Electricity & Internal Combustion Engine & $\begin{array}{l}\text { Metallurgy, Auto, } \\
\text { Machine Building }\end{array}$ & Train, Car \\
\hline III: $1960-2000$ & $1980-2000$ & $\begin{array}{l}\text { Nuclear Energy, } \\
\text { Natural Gas }\end{array}$ & Computers, Robots & Auto, Chemistry & Car, Plane \\
\hline IV: 2000- & $2000-2010$ & Green Energies & $\begin{array}{c}\text { Internet, 3D Printer, Genetic } \\
\text { Engineering }\end{array}$ & High Tech Industries & $\begin{array}{c}\text { Electric Car, } \\
\text { Ultra-Fast Train }\end{array}$ \\
\hline
\end{tabular}

In essence, the concept of the fourth industrial revolution was officially introduced in 2011 by Schwab (2016), President of the World Economic Forum in Davos as a proposal to develop high-tech strategies of Virtue [48, 77]. The fourth industrial revolution is listed with nine pillars of technological progress, shown in Table 4.

Table 4. The nine pillars of technological advancement

\begin{tabular}{cl}
\hline Technology Category & \\
\hline $\begin{array}{c}\text { Big Data and Data } \\
\text { Analytics }\end{array}$ & $\begin{array}{l}\text { Composed of characteristics called "V"s, such as volume, velocity, variety, and veracity, big data is a term that refers } \\
\text { to the large growing data sets that are collected using digital communication devices from satellites to smart phone } \\
\text { applications, which are stored in computer databases and 'mined' by computer advanced algorithms. }\end{array}$ \\
\hline & $\begin{array}{l}\text { The progress of technology enables researchers to create advanced machines that can perform increasing numbers of } \\
\text { tasks autonomously without human control or supervision. In this sense, intelligent autonomous systems operating in } \\
\text { physical environments - the so-called autonomous robots which have long been used in manufacturing-are } \\
\text { becoming more autonomous, flexible, and cooperative. }\end{array}$ \\
Autonomous Robots & $\begin{array}{l}\text { In the Industry 4.0 context, simulations will be used more extensively in plant operations to mirror the physical world } \\
\text { in a virtual model, which can include machines, products, and humans, reducing the time of configuration of the } \\
\text { machine, shortening downtime, reducing production failures, and increasing the quality and speed of decision- } \\
\text { making. }\end{array}$ \\
\hline $\begin{array}{c}\text { System Integration: } \\
\text { Horizontal and Vertical } \\
\text { System Integration }\end{array}$ & $\begin{array}{l}\text { The technological breakthroughs behind the Industry 4.0 revolution require corporations to adapt their production } \\
\text { mode with the aim of creating operational synergy and providing competitive advantages within the value chain } \\
\text { production system. }\end{array}$ \\
\hline
\end{tabular}




\begin{tabular}{cl}
$\begin{array}{c}\text { The Industrial Internet of } \\
\text { Things }\end{array}$ & $\begin{array}{l}\text { The main concept of the Internet of things (IoT) is to connect smart objects within cyber-physical systems, where } \\
\text { objects will interact with each other and can be supervised remotely by users. With this in mind, a definition of the } \\
\text { industrial Internet of things (IoT) may be the use of certain IoT technologies in an industrial setting or manufacturing } \\
\text { for the promotion of goals distinctive to industry. }\end{array}$ \\
\hline $\begin{array}{c}\text { Cybersecurity and Cyber- } \\
\text { Physical Systems (CPS) }\end{array}$ & $\begin{array}{l}\text { Cyber-physical systems (CPS) arise through devices for interaction between computing objects, people, and the } \\
\text { physical environment, and they include systems such as smart grids. Enabled with the IoT, CPS help in the process of } \\
\text { collecting, storing, and managing data. }\end{array}$ \\
\hline The Cloud & $\begin{array}{l}\text { The integration between the IoT and the cloud with respect to the Industry } 4.0 \text { revolution can help in the unfolding of } \\
\text { data management problems in a way that guarantees better accessibility and viability of the services. Cloud } \\
\text { computing enables hosted services to be delivered more efficiently through a software development platform to } \\
\text { process the large amount of data generated by the IoT. }\end{array}$ \\
\hline Additive Manufacturing & $\begin{array}{l}\text { Additive layer fabrication is used to construct or assemble parts so that the product prototype can be available } \\
\text { quickly and changed according to the customer's needs. With the advances of the Fourth Industrial Revolution and } \\
\text { increasing technological adaptation, the capacity of additive manufacturing has grown from the optimization of } \\
\text { configurations. }\end{array}$ \\
\hline Augmented Reality & $\begin{array}{l}\text { Through Industry 4.0, augmented reality has become one of the most exciting technologies to invest in due to the } \\
\text { emerging concept of intelligent manufacturing, and it can be used as a support for maintenance operations. }\end{array}$
\end{tabular}

The strides to create this fourth industrial revolution are supported by nine cutting-edge technological advancements that optimize production operations towards automation and higher production efficiency much more than that produced in previous technological revolutions [50].

\subsection{Opportunities of the Fourth Industrial Revolution}

Nine fundamental technological advances of the fourth technological revolution have created unprecedented breakthroughs in manufacturing, modern production leads to superior labor efficiency compared to traditional production [50] Not only increasing labor efficiency, connecting billions of people with mobile devices, technological devices with powerful information processing capabilities and knowledge storage, unlimited access to the limits that this revolution creates. Powerful applications of artificial intelligence, robotics, internet of things, autonomous vehicles, 3D printing, nanotechnology, biotechnology, new materials technology, energy storage and quantum computing Unlike previous technological revolutions, the fourth technological revolution will completely and profoundly transform people's lives [51]. Xu et al. (2018) affirmed the advantages that the fourth industrial revolution creates for people [47]:

- Shorten the time from the invention to the time the product is produced;

- Artificial intelligence has outstanding intelligence;

- Big Data;

- The Birth of Robots;

- Internet of Things.

The fourth industrial revolution also brings prosperity to the countries involved in the process. The application of the fourth technological revolution gradually replaces traditional labor with modern technologies, and humanity will enter a new era of knowledge. Cities are becoming smarter, and infrastructure, education, health, public safety, transportation and application-based public services incorporate software systems [49]. Jee (2017) argues that the fourth technological revolution will improve the quality of life of many people around the world, open up new markets and promote economic growth [52].

The birth of the fourth technological revolution has brought prosperity to countries, the emergence of the concepts of smart city, smart government, digital nation, etc. are gradually becoming more and more popular "reality". The advantages that the fourth industrial revolution brings to people are undeniable, but it also has a downside, challenges that need to be solved on the way to realizing the fourth technological revolution.

\subsection{Challenges of the Fourth Industrial Revolution}

In the context of the profound, comprehensive effects of the fourth technological revolution that has led to profound changes, it is necessary to consider the possible negative social impacts. Need to be forecasted and resolved soon, otherwise too slow forecasting or no early governance measures will lead to chaos such as problems of job retention and thus income generation, inequality, the practice of democratic values are central issues facing emerging economies [53]. Moreover, when applying advanced technology of the fourth technological revolution, some criminal activities will be more sophisticated, complex and difficult to manage in society.

According to Wolf (2015), technologies in the fifth technological revolution will replace manual labor. In contrast to jobs, jobs that require specialized skills are easier to find and less likely to be replaced, which can have social 
consequences such as increasing social conflicts “association”. Szudejko (2015) also reaffirmed that the changes in the fourth technological revolution still have profound and comprehensive effects on the economic system, social welfare, and political life and are difficult to undo $[53,54]$.

When the connection on the basis of modern technology will arise network security, one of the technologies that plays the role of a pillar for the development and success of the industrial revolution 4.0. Information security is always a key factor, especially in the context of internationalization, infiltrating the network security system is always an issue that receives special attention "difficulty during control". The higher the level of connectivity, the more important the areas are, the more requirements are placed in the control of internal and external processes, which will cost more resources to establish a secure system. Therefore, many countries have to spend a lot of money to protect the security and safety of the information system and reduce potential threats, even when the problem occurs, it is also very difficult to overcome the consequences "difficult" [55]. This fact shows that governments and organizations always face many challenges, especially emerging countries that do not have much experience in responding to risks caused by the application of technology. Romney and John (2006) issued a warning that the threats and losses from cyber-attacks are getting bigger and bigger [56].

\section{Impact of the Fourth Industrial Revolution on Ethical Leadership}

The presence of the fourth technological revolution brings ethical leadership to a new level, ethical leadership easily leads employees to achieve organizational goals. Decision making may seek the assistance of artificial intelligence for data analysis. Ethical leaders can create a collaborative working environment for employees in all areas and between leaders and employees easily overcome all language barriers, help organizations save costs, and leaders can perform their leadership role anytime, anywhere [57, 58].

Vandenberg (2020) and Radziwill (2018) all agree that technological advances are rapidly changing the way we can change the way we live and work, the way we interact $[59,60]$. The basic message is that society needs to deal with the changes caused by the impact of the fourth industrial revolution, in which people inherit comprehensive advances in economy, society, employment, etc. [61] but if we do not learn how to adapt, lack the initiative of leaders, especially governments and organizations, the risk of failure will be very high. Leaders themselves need to be aware of the advantages as well as potential risks, accurately forecast to promptly react accurately to the rapid changes of the impact context of the second industrial revolution.

Hinton (2018) [62] argues that the advanced technologies of the fourth technological revolution such as artificial intelligence and the internet of things are changing the role of leaders from individual decision-making models to decision-making. Collective decisions become flexible based on the consensus of the organization, fairness, at this time the leader cannot be autocratic but must share power, individual power will decrease but increase collective power "body". And for this transformation, according to Schrum et al. (2011) [63], up to 92\% of leadership preparation courses were not related to the dissemination of technology application, by 2019, according to like Raman and Thannimalai (2019) [64] most of the teaching content in schools has requirements to disseminate modern technology, leaders who are not successful in the current context are due to lack of technology applications. Advanced in leadership activities, leaders lack understanding of technology applications in religious activities. The application of technology requires leaders to be dedicated and more effort, as an example of work ethic and to attract people with technology skills to work.

Today's rapidly changing leadership landscape has forced leaders to be freed from their day-to-day tasks to focus more on strategic transformation, leaving them with little choice but to do so. Adopting technologies such as the internet of things, robotic process automation, 3D printing, blockchain, augmented reality and virtual reality as quickly as possible, but recommending that leaders still adhere to common ethical standards [65]. The fourth technological revolution that increases leadership performance is not only based on advanced technology applications, more importantly, leaders need to apply values and ethical standards to leadership activities to develop When leaders are willing to accept responsibility for themselves, they dare to do it, dare to take responsibility for failures, and defend the right [66].

Ethical leadership is also considered an art to influence when the leader uses his or her own example as a model to motivate and attract employees to believe and act according to Kitchener (1984) [39] and there is the impact of the fourth technological revolution, it seems that ethical leadership has more advantages to affirm the leader's ethical values with many channels of information, the response to the leadership context, leadership, and leadership decisions will be more accurate [67]. Not actively applying the technology of the fourth technological revolution to leadership is already a failure, but a bigger failure is that the leader leaves or pays little attention to ethical leadership to pursue the same mission. Common mission, goals, willingness to accept differences, individual responsibility in pursuing activities for the common good [68]. The fourth industrial revolution that increases leadership performance and resonates with leadership will further increase leadership performance and lead to sustainability not only in leadership performance but also in leadership performance. Sustainability in the development strategy of organizations or governments. 
Besides the positive effects of the fourth technological revolution on ethical leadership, there may be undesirable effects as pointed out by Firdaus (2019) [69], the fourth industrial revolution has may have negative effects on ethical leadership, robotics and artificial intelligence must adhere to ethical standards and principles, and should be treated and evaluated fairly. The effects of the fourth technological revolution that can corrupt ethical leadership, integrity, transparency, inadequately respected or ignored values and ethical standards will lead to when it comes to crises in leadership, intentional deviations are blamed on technology [70]. When ethical leadership does not represent the progressive values of society and does not pay attention to the advances of the fourth technological revolution, a highly intellectual product of contemporary society, it will be very difficult for organizations to advance to civilized levels.

The fourth technological revolution was born to serve the society to become more prosperous and better, the goal of ethical leadership is also to make the society better. Values of the fourth industrial revolution and ethical leadership are combined and resonate with each other, which will be good conditions and positive advantages for the formation and development of society to a higher level of civilization. In contrast, only ethical leadership without modern technology, society is still only a backward society, especially progressive, conservative moral leaders will become evil. This has the impact of the fourth technological revolution that will create a disaster for society. Advanced science and technology fall into the hands of unscrupulous people, most likely the unscrupulous people will pull back the progress of the nation, of humanity. The fourth industrial revolution itself is not bad, but if it is taken advantage of by the wicked and unethical people, the value of the fourth industrial revolution will become meaningless.

\section{Theoretical Approach}

Research Analysis: Fourth Industrial Revolution: Ethical Leadership Development was conducted based on a literature review with the same topic and similar keywords as this study: ethics; leadership, ethical leadership and the fourth industrial revolution. The study was performed in the Science Direct, Web of Science and Scopus databases because of their relevance. After collecting and selecting relevant research works, data mining is conducted according to the deductive method to clarify the concepts of ethics, leadership, ethical leadership, the public revolution. Fourth Industrial Revolution, the impacts of the fourth industrial revolution on ethical leadership in terms of both advantages and challenges, the research process is shown in Figure 1. Perspective by Ceci et al. (2012) [71], the articles were collected and sorted according to the process of extracting the issues related to the research work to identify the keywords with the highest frequency of occurrence and the relationship between them. Their relationship to show that international scientists have solved problems related to the fourth industrial revolution [49], this study will explore how this industrial revolution has impacted to ethical leadership.

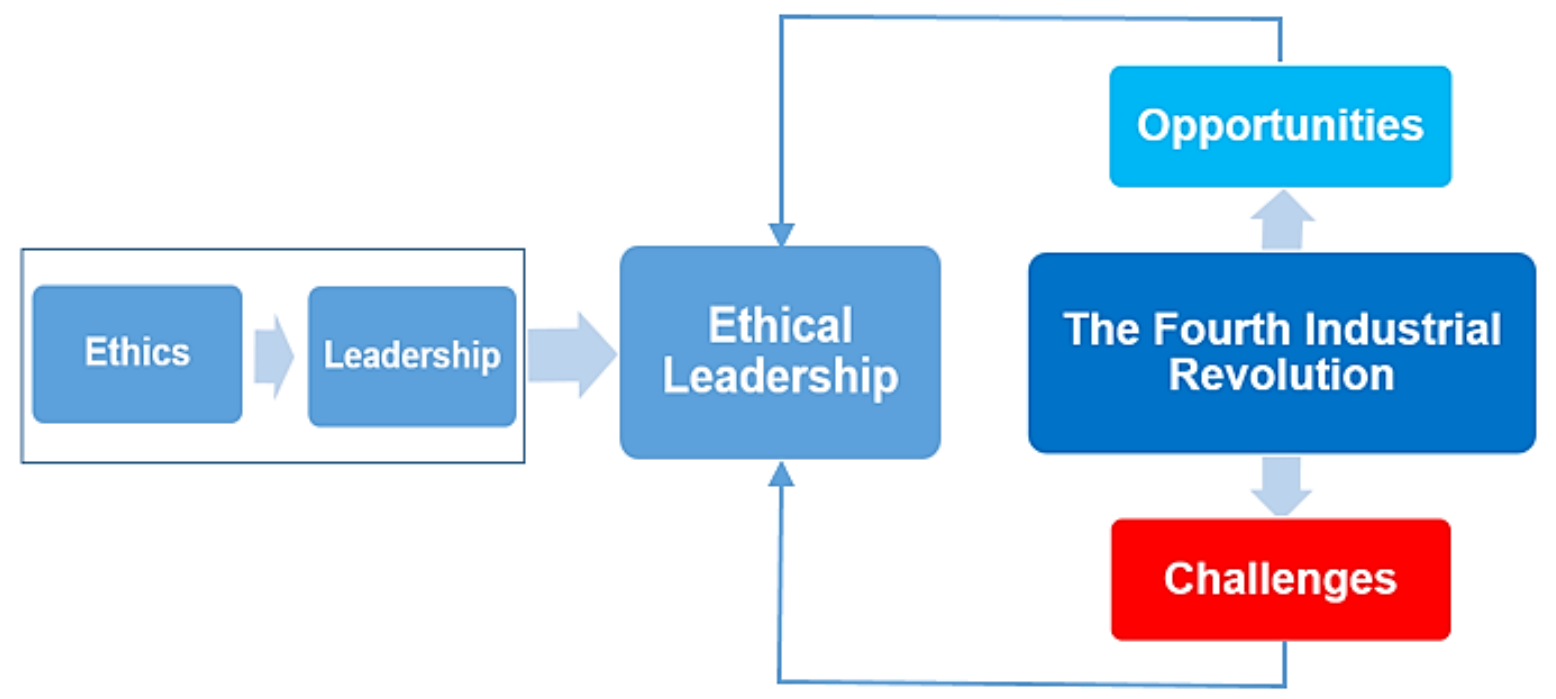

Figure 1. Flowchart of Research Methodology

Modern research on leadership often tends to combine leadership theories because of the concept that it will increase leadership performance and so far the theory of ethical leadership has not been fully developed [72]. Before the strong development of the fifth technological revolution, there will be certain impacts on ethical leadership on both advantages and challenges. Especially given the challenges posed by the fourth technological revolution can heal corrupt ethical leadership. Therefore, the theoretical framework will follow the direction of pointing out the positive effects and advantages that contribute to further increasing ethical leadership, minimizing the negative impacts of the fourth industrial revolution on leaders. Ethics, highlighting the very important role of ethical leadership in the fourth industrial revolution. 


\section{Discussion}

True values of the fourth industrial revolution do not change the role and nature of ethical leadership, it should be seen that the impact of the fourth industrial revolution highlights the role of leaders "virtue". Leadership in the current context, ethical leadership needs to overcome challenges and take advantage of advantages [73]. The achievements of the fourth industrial revolution will make leaders more skilled and therefore more accurate in decision-making skills, especially the influence of emotions on leadership decisions. Less, decisions will involve more reason. Furthermore, employees will be involved in the decision-making process because they are the subject of leadership decisions [74]. However, for the effects of ethical leadership to be truly meaningful, the key point in ethical leadership is the need to follow the ethical principles that justice must be done fairly and equally. , honesty and truth, responsibility, humanity, devotion, tolerance, etc. [75]. Thus, the fourth industrial revolution without strong moral leadership bad things will come very quickly [76]. Atkinson (2019) [76] also argues that much of the world's current leadership corruption problems can be traced back to the advancement of technology. But as technology advances, some leaders who try to maintain leadership in the traditional way that is based mainly on virtue have failed, and are not willing to accept and apply technology in leadership activities. Failure seems to be foretold.

The father of the concept of the fourth industrial revolution Schwab (2016) [77] also reminds us that the fourth industrial revolution creates a prosperous future, but we must be aware of those effects, efforts must focus on people, for the advancement of society and not only on technological progress or economic productivity. Leaders must give leadership so that employees can master technology and advocate for progress, conservatism and obsolescence will stifle positive transformation, social self-determination will be nullified [78].

Before the impacts of the fourth technological revolution, ethical leadership will more or less change, but the principle of ethical leadership must have stability and consistency, the basic values are pointed out. That is the spirit of service, altruism, kindness, tolerance, justice, sharing of power, and the pursuit of common moral standards [79-81]. When ethical leadership is corrupted, positive leadership values will be discarded, ethical leadership will become unethical leadership, and the effects of the fourth industrial revolution will no longer be valid. On the contrary, it will become anti-progressive, organizations, governments, or humanity will have to face a greater challenge because the fourth industrial revolution has acted in the wrong place [82]. The role of ethical leadership will become more and more essential. The more strongly the principle of ethical leadership must be enforced, as society advances further and further in technology.

Zervoudi (2020) [83] warns of the negative consequences of the fourth industrial revolution, claiming that the rate of unemployed and laid-off workers will rise as a result of technological advances, increased exposure of workers to the risk of automation, the threat of nuclear disaster, income gap and social inequality, espionage activities, and political interference. Ethical leadership is a strategic strategy to deal proactively and effectively with the unpredictable consequences of technological progress. Technology can replace and liberate human labor, but ethical leadership is irreplaceable. It needs to be developed and deepened with each advancement of technology.

So, the question is whether ethical leadership is considered an ideal leadership model or not. The answer will not be just yes or no, because ethical leadership must also adapt to the cultural context, political institutions, and social environment. Ciulla $(1995,2020)$ affirmed the leader, ethical leadership as an effective leader, he does not claim that ethical leadership is an ideal model. In any leadership context, political institution or culture, to what extent the impact of the fourth industrial revolution is profound, ethical leadership qualities still have standards, general principles: consensus in the organization, leaders become dedicated, dedicated servants, examples of compassion, tolerance, promoting fairness, transparency and accountability, In pursuing common standards and always standing for the right, daring to commit to fighting the bad and the immoral, the leader must first have a spirit of service $[84,85]$. Before the impacts of the fourth industrial revolution, the values, principles, and ethical leadership standards must be higher and more consistent. The more drastic changes are made in society, ethics as a value becomes a standard to keep stability [86]. In contrast, weak, unethical leadership is also a barrier to implementing the goals and strategies to realize the fourth industrial revolution [87].

On the other hand, ethical leadership is also relatively backward, so along with the impacts of the fourth industrial revolution, leaders need to have enough cognitive capacity and alertness to recognize the ethical leadership qualities that need to change, and at the same time supplement and develop new ethical leadership qualities to meet the practical requirements of the fourth industrial revolution. Knights (2018) [88] affirms that developing ethical leadership will create trust among stakeholders, ensure long-term sustainability of the organization, ensure informed decision making, ensure consistency in a leadership environment that is volatile and promotes a framework of transparency. Therefore, along with the effects of the fourth industrial revolution, it is necessary to simultaneously develop ethical leadership that corresponds to the change of advanced technology. Ethical leadership development will produce leaders who are dedicated, responsible for the organization's mission, who have determination and perseverance in pursuing good ethical leadership values [89], which are wise strategies that organizations must pay attention to keep stability and development, and respond well to the challenges of the new leadership context [90]. 


\section{Conclusion}

Today, ethical leadership plays a very important role in the leader's qualities, making the leader steadfast and ready to overcome difficulties in the face of challenging leadership contexts. The effects of the fourth industrial revolution will not reduce the quality and values. On the contrary, they will make the manifestations of ethical leadership: voluntariness, service spirit, altruism, kindness, tolerance, justice, sharing of power, protection of justice, goodness, fairness against corruption, unethical acts. Ethical leadership also has an impact on the implementation of the fourth industrial revolution, making the values of the fourth industrial revolution change social life in a positive way and bringing prosperity to the organization and to society. The impact of the fourth industrial revolution on ethical leadership has good value on the contrary, the impact on unethical leadership will produce negative variations, which are evil, counterproductive, and negative "improvement". Therefore, it is necessary to train and develop leaders that are inseparable from the task of developing ethical leaders.

Poor moral leadership will be the biggest barrier to realizing the strategy of the fourth industrial revolution. Therefore, ethical leadership becomes an essential part, an important foundation in the strategy of ethical leadership development, to be able to effectively apply leadership to the impacts of the fourth industrial revolution. successful in promoting the comprehensive development of social life, especially in emerging countries, where many ethical leadership values are being shaped and developed by the impact of the second industrial revolution. Fourth, make these effects more advanced than unethical leadership, avoid the impact on unethical leadership.

\section{Declarations}

\subsection{Author Contributions}

Conceptualization, T.N.H and Q.N.V.; writing - original draft preparation, T.N.H. and Q.N.V.; writing - review and editing, T.N.H. and Q.N.V.; All authors have read and agreed to the published version of the manuscript.

\subsection{Data Availability Statement}

Data sharing is not applicable to this article.

\subsection{Funding}

The authors received no financial support for the research, authorship, and/or publication of this article.

\subsection{Institutional Review Board Statement}

Not applicable.

\subsection{Informed Consent Statement}

Not applicable.

\subsection{Declaration of Competing Interest}

The authors declare that there is no conflict of interests regarding the publication of this manuscript. In addition, the ethical issues, including plagiarism, informed consent, misconduct, data fabrication and/or falsification, double publication and/or submission, and redundancies have been completely observed by the authors.

\section{References}

[1] Hwang, K.-K. (2015). Morality "East" and "West": Cultural Concerns. International Encyclopedia of the Social \& Behavioral Sciences, 806-810. doi:10.1016/b978-0-08-097086-8.64005-9.

[2] Brown, M. E., Treviño, L. K., \& Harrison, D. A. (2005). Ethical leadership: A social learning perspective for construct development and testing. Organizational Behavior and Human Decision Processes, 97(2), 117-134. doi:10.1016/j.obhdp.2005.03.002.

[3] Sendjaya, S. (2005). Morality and leadership: Examining the ethics of transformational leadership. Journal of Academic Ethics, 3(1), 75-86. doi:10.1007/s10805-005-0868-7.

[4] Kunhiyop, S. W. (2009). African Christian Ethics. Zondervan: Grand Rapids, California, United States.

[5] Bass, B. M., \& Riggio, R. E. (2018). Transformational Leadership, Ho Chi Minh City. Ho Chi Minh City Publishing House, Hanoi, Vietnam.

[6] Grossman, R. J. (2015). Persistence in leader selection rescues arrow electronics in its darkest hours. Journal of Leadership Studies, 8(4), 40-48. doi:10.1002/j1s.21345.

[7] Poff, D. C. (2004). Challenges to Integrity in University Administration: Bad Faith and Loyal Agency. Journal of Academic Ethics, 2(3), 209-219. doi:10.1007/s10805-005-0502-8. 
[8] Ciulla, J. B. (2005). Integrating leadership with ethics: Is good leadership contrary to human nature? In Handbook on Responsible Leadership and Governance in Global Business (pp. 159-179). Edward Elgar Publishing. doi:10.4337/9781845425562.00017.

[9] Le, N. H. (2011) Lao Tu ethics, Ho Chi Minh City. Ho Chi Minh City Publishing House, Hanoi, Vietnam.

[10] Krishnamurthy, P. (2011). An Introduction to Ethics. SSRN Electronic Journal. doi:10.2139/ssrn.1781502.

[11] Spencer, H. (2011). Absolute ethics and relative ethics. In The principles of ethics Vol. 1, pp. 258-280. D Appleton Company. doi:10.1037/12965-015.

[12] Northouse, P. G. (2021). Leadership: Theory and practice. Sage publications, California, United States.

[13] Dancy, J. (2005). Ethics without Principles. In Ethics without Principles. Oxford University Press. doi:10.1093/0199270023.001.0001.

[14] DeGrazia, D., \& Beauchamp, T. L. (2020). Principles of Animal Research Ethics. In Principles of Animal Research Ethics (pp. 5-42). Oxford University Press. doi:10.1093/med/9780190939120.003.0001.

[15] Ferreres, A. R. (2019). Foundations and Principles of Surgical Ethics. In Surgical Ethics (pp. 45-52). Springer International Publishing. doi:10.1007/978-3-030-05964-4_4.

[16] Haiming, W. (2020). Introduction to the Principles of New Ethics. In The Principles of New Ethics I (pp. 1-40). Routledge. doi:10.4324/9780429447211-1.

[17] Murphy, J. T., \& Cuban, L. (1990). The Managerial Imperative and the Practice of Leadership in Schools. In History of Education Quarterly 30(2). SUNY Press. doi:10.2307/368679.

[18] Hung, L. N. (2018) Theories of leadership and management in front of the fundamental and comprehensive requirements of education in Vietnam. Portal of the People's Police Academy. Available online: http://hvcsnd.edu.vn/nghien-cuu-traodoi/giao-duc-dao-tao/cac-ly-thuyet-lanh-dao-quan-ly-truoc-yeu-cau-doi-moi-can-ban-toan-dien-giao-duc-o-viet-nam-4641 (accessed on May 2021).

[19] Stogdill, R. M. (1974). Handbook of Leadership, A Survey of the Literature. In Journal of Business Communication, 12(2). Free Press. doi:10.1177/002194367501200210.

[20] Jacobs, T. O., \& Jaques, E. (1990). Military executive leadership. In Measures of Leadership (pp. 281-295). Leadership Library of America, New Jersey, United States.

[21] Hayyat Malik, S. (2012). A Study of Relationship between Leader Behaviors and Subordinate Job Expectancies: A Path-Goal Approach. Pakistan Journal of Commerce \& Social Sciences, 6(2), 357-371.

[22] Kesting, P., Ulhøi, J. P., Song, L. J., \& Niu, H. (2015). The impact of leadership styles on innovation management - a review and a synthesis. Journal of Innovation Management, 3(4), 22-41. doi:10.24840/2183-0606_003.004_0004.

[23] Vonderlin, R., Schmidt, B., Müller, G., Biermann, M., Kleindienst, N., Bohus, M., \& Lyssenko, L. (2021). Health-Oriented Leadership and Mental Health from Supervisor and Employee Perspectives: A Multilevel and Multisource Approach. Frontiers in Psychology, 11. doi:10.3389/fpsyg.2020.614803.

[24] Bass, B. M., \& Bass, R. (2009). The Bass Handbook of Leadership: Theory, Research, and Managerial Applications. Free Press, New York, United States.

[25] Rebore, R. W. (2003). A Human Relations Approach to the Practice of Educational Leadership. Pearson Allyn and Bacon, Massachusetts, United States.

[26] Silva, A. (2016). What is Leadership? Journal of Business Studies Quarterly, 8(1), 1-5.

[27] Maxwell, J. C. (2016) Developing leadership skills, Hanoi: Lao Dong Publishing House, Hanoi, Vietnam.

[28] Gilligan, C. (1993). In a different voice: Psychological theory and women's development. Harvard University Press, Massachusetts, United States.

[29] DePree, M. (1989). Leadership is an art. Bantam Doubleday Dell Publishing Group, New York, United States.

[30] Covey, S. (1990). Principle-centered leadership. New York: Simon \& Simon. Cronin, JJ, \& Taylor, SA (1992). Measuring service quality: A reexamination and extension. Journal of Marketing, 56(7), 55-68.

[31] Block, P. (1993). Stewardship: Choosing service over self-interest. Berrett-Koehler Publishers, California, United States.

[32] Kouzes, J. M., \& Posner, B. Z, (1995). The leadership challenge: How to keep getting extraordinary things done in organizations, 2 ed., Jossey-Bass, San Francisco, United States.

[33] Bass, B. M., \& Steidlmeier, P. (1999). Ethics, character, and authentic transformational leadership behavior. Leadership Quarterly, 10(2), 181-217. doi:10.1016/S1048-9843(99)00016-8. 
[34] Gini, A. (1997). Moral leadership and business ethics. Journal of Leadership Studies, 4(4), 64-81.

[35] Kanungo, R. N., \& Mendonca, M. (1996). Ethical dimensions of leadership. In Choice Reviews Online (Vol. 33, Issue 08). Sage. doi:10.5860/choice.33-4607.

[36] Beauchamp, T. L., Bowie, N. E., \& Arnold, D. G. (2004). Ethical theory and business, Pearson Education, London, UK.

[37] De Hoogh, A. H. B., \& Den Hartog, D. N. (2008). Ethical and despotic leadership, relationships with leader's social responsibility, top management team effectiveness and subordinates' optimism: A multi-method study. Leadership Quarterly, 19(3), 297-311. doi:10.1016/j.leaqua.2008.03.002.

[38] Yukl, G. (2012). Effective leadership behavior: What we know and what questions need more attention. Academy of Management Perspectives, 26(4), 66-85. doi:10.5465/amp.2012.0088.

[39] Kitchener, K. S. (1984). Intuition, Critical Evaluation and Ethical Principles: The Foundation for Ethical Decisions in Counseling Psychology. The Counseling Psychologist, 12(3), 43-55. doi:10.1177/0011000084123005.

[40] Rost, J. C. (1991). Leadership for the twenty-first century. Greenwood Publishing Group, Connecticut, United States.

[41] Burns, J. M. (1978). Leadership. By Burns James MacGregor. American Political Science Review, 74(01), 153-156.

[42] Mihelic, K. K., Lipicnik, B., \& Tekavcic, M. (2010). Ethical Leadership. International Journal of Management \& Information Systems (IJMIS), 14(5). doi:10.19030/ijmis.v14i5.11.

[43] Selznick, P., McEwan, I., Yukl, G. A., \& VanFleet, D. D. (2002). Leadership in organizations. Russel Sage, New York, United States.

[44] Cheteni, P., \& Shindika, E. S. (2017). Ethical leadership in South Africa and Botswana. BAR - Brazilian Administration Review, 14(2), 1-19,. doi:10.1590/1807-7692bar2017160077.

[45] Lao Tu, (1972). Ethics code, Vol. 2. Khai Tri bookstore, Paris, France.

[46] Ink, Dwight. (2014) Twenty-First-Century Career Leaders. Transforming Public Leadership for the 21st Century, 61-82. doi:10.4324/9781315698588-11.

[47] Xu, M., David, J. M., \& Kim, S. H. (2018). The fourth industrial revolution: Opportunities and challenges. International Journal of Financial Research, 9(2), 90-95. doi:10.5430/ijfr.v9n2p90.

[48] Feshina, S. S., Konovalova, O. V., \& Sinyavsky, N. G. (2019). Industry 4.0-transition to new economic reality. In Studies in Systems, Decision and Control, 169, 111-120). Springer. doi:10.1007/978-3-319-94310-7_11.

[49] Gonçalves, G. D. L., Filho, W. L., Neiva, S. da S., Deggau, A. B., Veras, M. de O., Ceci, F., de Lima, M. A., \& Guerra, J. B. S. O. de A. (2021). The impacts of the fourth industrial revolution on smart and sustainable cities. Sustainability (Switzerland), 13(13), 1-21. doi:10.3390/su13137165.

[50] Rüßmann, Michael Lorenz, M., Gerbert, P., Waldner, M., Justus, J., Engel, P., \& Harnisch, M. (2015). Industry 4.0: The Future of Productivity and Growth in Manufacturing Industries. In The Boston Consulting Group. Boston Consulting Group.

[51] World Economic Forum, (2020) "The Global Risks Report," in World Economic Forum, Geneva, Switzerland.

[52] Jee, Y. S. (2017). Exercise rehabilitation in the fourth industrial revolution. Journal of Exercise Rehabilitation, 13(3), 255-256. doi:10.12965/jer.1735012.506.

[53] Szudejko, M. (2015). Same as It Ever Was: Why Techno-Optimists Are Wrong. CFA Digest, 45(12). doi:10.2469/dig.v45.n12.16.

[54] Wolf, M. (2015). Same as it ever was why the techno-optimists are wrong. Foreign Affairs, 94(4). doi:10.2469/dig.v45.n12.16.

[55] ESSS. (2017). Os Pilares Da Indústria 4.0: 25(1). Available online: https://www.esss.co/blog/os-pilares-da-industria-4-0/ (accessed on May 2021).

[56] Romney, M. B., \& John, P. (2009). Steinbart. Accounting Information Systems. Pearson, London, United Kingdom.

[57] Patel, A. (2019). How Technology Can Be Used to Empower Leadership. In About Leaders: Vol. 143 (pp. 1-7). Available online: https://aboutleaders.com/technology-empower-leadership/\#gs.8d0gf5 (accessed on March 2021).

[58] Lund, B. (2021). The fourth industrial revolution. In Information Technology and Libraries (Vol. 40, Issue 1). World Economic Forum. doi:10.6017/ITAL.V40I1.13193.

[59] Vandenberg, P. (2020). The fourth industrial revolution: by Klaus Schwab, Geneva, World Economic Forum, 2016,184 pp. Journal of the Asia Pacific Economy, 25(1), 194-196. doi:10.1080/13547860.2019.1686320.

[60] Radziwill, N. (2018). The Fourth Industrial Revolution: Klaus Schwab. 2016. World Economic Forum, Geneva, Switzerland. 184 pages. The Fourth Industrial Revolution: Klaus Schwab. 2016. World Economic Forum, Geneva, Switzerland. 184 Pages, 25(2), 108-109. doi:10.1080/10686967.2018.1436355. 
[61] Hai, T. N., Van, Q. N., \& Tuyet, M. N. T. (2021). Digital transformation: Opportunities and challenges for leaders in the emerging countries in response to covid-19 pandemic. Emerging Science Journal, 5(Special Issue), 21-36. doi:10.28991/esj2021-SPER-03.

[62] Hinton S., (2018) "How The Fourth Industrial Revolution Is Impacting The Future of Work," Forbes. Available online: https://www.forbes.com/sites/theyec/2018/10/19/how-the-fourth-industrial-revolution-is-impacting-the-future-ofwork/?sh=643e20c865a7. (accessed on May 2021).

[63] Schrum, L., Galizio, L. M., \& Ledesma, P. (2011). Educational Leadership and Technology Integration: An Investigation into Preparation, Experiences, and Roles. Journal of School Leadership, 21(2), 241-261. doi:10.1177/105268461102100205.

[64] Raman, A., \& Thannimalai, R. (2019). Importance of Technology Leadership for Technology Integration: Gender and Professional Development Perspective. In SAGE Open (Vol. 9, Issue 4, pp. 1-13,). doi:10.1177/2158244019893707.

[65] Aurik, J., Anscombe, J., \& Jonk, G. (2018). How technology can transform leadership - for the good of employees. World Economic Forum. Available online: https://www.weforum.org/agenda/2018/03/how-technology-can-transform-businessperformance-for-human-good/ (accessed on March 2021).

[66] Blackman, A. (2018). What Is Ethical Leadership? How to Be a More Ethical Leader. EnvatoTuts. Available online: https://business.tutsplus.com/tutorials/what-is-ethical-leadership--cms-31780 (accessed on March 2021).

[67] Weng, C. H., \& Tang, Y. (2014). The relationship between technology leadership strategies and effectiveness of school administration: An empirical study. Computers and Education, 76, 91-107. doi:10.1016/j.compedu.2014.03.010.

[68] Menzel, D. C. (1997). Teaching ethics and values: A survey of graduate public affairs and administration programs in the U.S. PS - Political Science and Politics, 30(3), 518-524. doi:10.1017/S1049096500046771.

[69] Firdaus, Q. (2019). Four ethical challenges in industry 4.0. The Jakarta Post. Available online: https://www.thejakartapost.com/academia/2019/01/08/four-ethical-challenges-in-industry-4-0.html (accessed on March 2021).

[70] Lanik, M. (2019). Effective Leadership Skills. Publishing House of National Economics University, Hanoi, Vietnam.

[71] Ceci, F., Pietrobon, R., \& Gonçalves, A. L. (2012). Turning text into research networks: Information retrieval and computational ontologies in the creation of scientific databases. PLoS ONE, 7(1), 27499. doi:10.1371/journal.pone.0027499.

[72] Kalshoven, K., Den Hartog, D. N., \& De Hoogh, A. H. B. (2011). Ethical leadership at work questionnaire (ELW): Development and validation of a multidimensional measure. Leadership Quarterly, 22(1), 51-69. doi:10.1016/j.leaqua.2010.12.007.

[73] Coldwell, D. A. L. (2017). Ethical Leadership in Crisis Management: The Role of University Education. Contemporary Leadership Challenges. doi:10.5772/65497.

[74] Zhang, Y., Zhou, F., \& Mao, J. (2018). Ethical leadership and follower moral actions: Investigating an emotional linkage. Frontiers in Psychology, 9(OCT), 1-11. doi:10.3389/fpsyg.2018.01881.

[75] Ahmad, I., Gao, Y., \& Hali, S. M. (2017). A Review of Ethical Leadership and Other Ethics- Related Leadership Theories. European Scientific Journal, 13(29), 10. doi:10.19044/esj.2017.v13n29p10.

[76] Atkinson, C. (2019) Moral Leadership in the 4th Industrial Revolution. Linkedin. Available online: https://www.linkedin.com/pulse/moral-leadership-4th-industrial-revolution-chris-atkinson (accessed on March 2021).

[77] Schwab, K. (2016). Four leadership principles for the fourth industrial revolution. World Economic Forum. Available online: https://www.weforum.org/agenda/2016/10/four-leadership-principles-for-the-fourth-industrial-revolution/ (accessed on May 2021).

[78] Frazier, M. L., \& Jacezko, M. C. (2021). Leader Machiavellianism as an Antecedent to Ethical Leadership: The Impact on Follower Psychological Empowerment and Work Outcomes. Journal of Leadership and Organizational Studies, 28(2), 154168. doi:10.1177/1548051820971293.

[79] Middlebrooks, A., Miltenberger, L., Tweedy, J., Newman, G., \& Follman, J. (2009). Developing a sustainability ethic in leaders. Journal of Leadership Studies, 3(2), 31-43. doi:10.1002/j1s.20106.

[80] Corzilius, O. (2020). The Fourth Industrial Revolution and its Impact on Ethics - Solving the Challenges of the Agenda 2030. DjbZ, 23(1), 37-38. doi:10.5771/1866-377x-2020-1-37.

[81] Van Dÿck, C. M. (2021). Digital Equity and the Fourth Industrial Revolution. The Fourth Industrial Revolution and Its Impact on Ethics, 115-120. doi:10.1007/978-3-030-57020-0_9.

[82] Tanguay, G. (2021). Addressing the Ethical and Social Challenges of Emerging Technologies: Creating the Conditions to Play a Leadership Role in the Fourth Industrial Revolution. The Fourth Industrial Revolution and Its Impact on Ethics, 1-13. doi:10.1007/978-3-030-57020-0_1. 
[83] K. Zervoudi, E. (2020). Fourth Industrial Revolution: Opportunities, Challenges, and Proposed Policies. In Industrial Robotics - New Paradigms. IntechOpen. doi:10.5772/intechopen.90412.

[84] Ciulla, J. B. (1995). Leadership Ethics: Mapping the Territory. Business Ethics Quarterly, 5(1), 5-28. doi:10.2307/3857269.

[85] Ciulla, J. B. (2020). Leadership and the power of resentment/ressentiment. Leadership, 16(1), 25-38. doi:10.1177/1742715019885772.

[86] Satterwhite, R., Sarid, A., Cunningham, C. M., Goryunova, E., Crandall, H. M., Morrison, J. L., Sheridan, K., \& Miller, M. (2020). Contextualizing our Leadership Education Approach to Complex Problem Solving: Shifting Paradigms and Evolving Knowledge: Priority 5 of the National Leadership Education Research Agenda 2020-2025. Journal of Leadership Studies, 14(3), 63-71. doi:10.1002/jls.21717.

[87] World Economic Forum. (2019). The 4 types of leader who will thrive in the Fourth Industrial Revolution. World Economic Forum. Available online: https://www.weforum.org/agenda/2019/01/these-four-leadership-styles-are-key-to-success-in-thefourth-industrial-revolution/ (accessed on March 2021).

[88] Knight, J. (2018). Transpersonal Leadership Series: White Paper One. How to Develop Ethical Leaders. Routledge, London, United Kingdom.

[89] Knapp, J. C., \& Olson, S. (1996). Ethical leadership. Journal of Leadership and Organizational Studies, 3(4), 84-86. doi:10.1177/107179199600300408.

[90] Sharma, A., Agrawal, R., \& Khandelwal, U. (2019). Developing ethical leadership for business organizations: A conceptual model of its antecedents and consequences. Leadership and Organization Development Journal, 40(6), $712-734$. doi:10.1108/LODJ-10-2018-0367. 